\title{
Geospatial delineation and mapping of groundwater potential in Embu County, Kenya
}

\section{Delimitazione geospaziale e mappatura del potenziale idrico sotterraneo nella contea di Embu, Kenya}

Mary Christine Chepchumba, James M. Raude, Joseph K. Sang

Riassunto: L'integrazione di tecniche di telerilevamento (RS, dall'inglese Remote Sensing) e sistemi informativi territoriali (GIS, dall'inglese Geographical Information System) costituisce un punto di avanzamento nel campo della gestione delle risorse idriche sotterranee. Le tecniche RS e GIS possono migliorare la valutazione, il monitoraggio e la conservazione delle risorse idriche sotterranee. In questo studio, le tecniche RS e GIS sono state applicate con l'obiettivo di identificare il potenziale idrico sotterraneo nella contea di Embu, in Kenya, sulla base di molteplici fattori di influenza selezionati. La mappa dei lineamenti è stata ottenuta dal trattamento delle immagini Landsat 8 ETM+ applicando l'analisi delle componenti principali mediante ENVI®4.7 ed estraendo automaticamente le tracce dei lineamenti applicando la PCA alle immagini satellitari mediante il modulo LINE del software Geomatica. La risultante mappa del potenziale idrico sotterraneo ha mostrato che circa il $78 \%$ dell'area totale variava da zone "alte" a "molto alte", indicando che quasi la metà dell'area di studio ha un buon potenziale idrico sotterraneo. Circa il $20 \%$ ha mostrato un potenziale moderato mentre solo il $2 \%$ è sceso sotto un basso potenziale. Il metodo di studio proposto può essere utilizzato come un nuovo approccio nel modellare i dati geospaziali per l'identificazione e la mappatura del potenziale idrico sotterraneo. I risultati dello studio sono utili per una pianificazione preliminare delle informazioni e per lo svolgimento, da parte delle autorità locali, della valutazione, pianificazione, gestione e amministrazione delle risorse idriche nella Contea di Embu.

Keywords: groundwater exploration, Principal Component Analysis, lineament extraction, remote sensing, geographic information system.

Parole chiave: analisi delle componenti principali, estrazione dei lineamenti, telerilevamento, sistemi informativi territoriali.

Mary Christine CHEPCHUMBA 棒"

James M. RAUDE, Joseph K. SANG

Department of Soil, Water and Environmental Engineering (SWEE)

Jomo Kenyatta University of Science and Technology (JKUAT), Kenya marychristinechepchumba@gmail.com

Ricevuto/Received: 18 December 2018-Accettato/Accepted: 30 March 2019 Pubblicato online/Published online: 16 May 2019

This is an open access article under the CC BY-NC-ND license: http://creativecommons.org/licenses/by-nc-nd/4.0/

(C) Associazione Acque Sotterranee 2019
Abstract: Integration of Remote Sensing (RS) and the Geographical Information System (GIS) approaches in the field of groundwater resources management is a breakthrough. The RS and GIS geospatial approaches can enhance the assessment, monitoring, and conservation of groundwater resources. In this study, RS and GIS geospatial techniques were applied with the aim of identifying groundwater potential zones in Embu County, Kenya, based on selected multi influencing factors. Lineament layer was obtained by processing Landsat 8 ETM+ image using Principal Component Analysis in ENVI®4.7 and automatic extraction from Principal Component Image using the LINE module in Geomatica software. The resultant groundwater potential map showed that approximately $78 \%$ of the total area ranged from 'bigh' to 'very high' zones indicating that almost half of the study area has good groundwater potential. About $20 \%$ showed moderate potential while only $2 \%$ fell under the low potential zone. The proposed study approach can be used as a new way of modeling geospatial data for identification and mapping of groundwater potential zones. The study findings are useful to first-hand information planners and local authorities for assessment, planning, management and administration of groundwater resources in Embu County.

\section{Introduction}

Key amongst the rights and fundamental freedoms in the Constitution of Kenya (CoK) 2010, is the right of every person to access clean and safe water in adequate quantities. Further, in Kenya's blueprint, the vision 2030, the vision for water and sanitation is to ensure that improved water and sanitation are available and accessible to all through conservation of water sources and implementation of new ways of harvesting and using rain and underground water (Kenya Vision 2030, 2010). The prioritization of access to water is informed by the fact that over $80 \%$ of Kenya's surface area is semi-arid and arid agro-ecologies (JICA 2012). This means that Kenya is a water scarce country. Groundwater is one of the most valuable natural resources serving as a significant source of water to communities, agricultural and industrial purposes (Rahmati et al. 2016) though currently under-exploited in Kenya (JICA 2012). Compared to other water sources, groundwater is less vulnerable to climate fluctuations in an undisturbed aquifer system and therefore, can act as a critical buffer against drought and variations in rainfall (Balamurugan et al. 2017). Hence, the need to identify and map groundwater potential zones for groundwater development and effective 
water resource management (Mati et al.,2005) in water-scarce regions of Kenya is paramount.

There is no direct method to facilitate observation of water below the surface. However, the presence or absence of groundwater can only be inferred indirectly by studying the geological and surface parameters. Test drilling and stratigraphic analysis are the most reliable and standard methods for determining the location for drilling a borehole and the corresponding thickness of the aquifereous unit (Jha et al. 2010). The traditional approach of groundwater exploration through drilling, geological, hydro-geological, and geophysical methods are costly and time-consuming (Sander et al. 1996; Singh et al. 2002; Rahmati et al. 2016). Such methods suffer failure rates significantly depending on the resources and expertise available (Lee et al. 2015). However, the failure rates can be reduced by utilizing Geographic Information System (GIS) and remote sensing (RS) techniques.

GIS and RS technologies have great potential for use in groundwater potential analyses (Lee et al. 2015). Systematic integration of information about surface features related to groundwater such as landforms, land use, and lineaments is an essential aspect of GIS (Nampak et al. 2014; Lee et al. 2015). In the recent past, GIS and RS have been applied extensively in groundwater-related studies (Balwant et al. 2018; Mokadem et al. 2018, Senthil 2017; Thomas and Duraisamy 2017; Hornero et al. 2016; Mogaji et al. 2012; Mallast et al. 2011). It is not possible to directly understand groundwater distribution using RS and GIS technologies without field surveys, but groundwater potential can be inferred from surface attributes such as geology, soil texture, land use, and drainage systems of a watershed (Dinesh-Kumar et al. 2007; Machiwal et al. 2011; Lee et al. 2015).

To understand groundwater systems, the physical characteristics of the related factors that configure the system should be identified (Lee et al. 2015). Generally, the occurrence and productivity of groundwater in a given aquifer are influenced by geo-environmental factors (Rahmati et al. 2016) such as landforms, drainage density, slope steepness, lineaments, land use, and land cover (Oh et al. 2011). The information about geo-environmental factors related to groundwater can be extracted through RS data (Nampak et al. 2014) and integrated with a GIS environment followed by spatial analysis and visual interpretation (Jha et al. 2007; Tiwari et al. 2017). An integrated analysis of these geo-environmental factors can be critical in identifying and delineating the potential high yielding groundwater zones in a cost-effective manner. This can help in narrowing down the target areas for conducting detailed hydrogeological and geophysical surveys on the ground, and ultimately to locate the site for drilling.

Over $80 \%$ of Kenya's land mass are agriculturally lowpotential areas due to low and erratic rainfall (JICA 2012). These areas constitute the bulk of the marginal sub-humid, semi-arid and the arid agro-ecologies. Currently, most of these low potential areas are experiencing an increase in population pressure resulting from an influx of immigrants from the over-populated neighbouring high potential areas (Ngetich et al. 2014). The immigrants are searching for greener grazing lands, and good livelihood means. To worsen the situation, there has been a chronic recurrence of severe droughts leading to regular water shortage (Huho 2010).

On the other hand, the demand for groundwater which is the primary source of water in these agro-ecologies is increasing. This informed groundwater potential mapping in this study to support exploration and exploitation thus complementing other water sources in the marginal sub-humid, semi-arid and the arid agro-ecologies. Consequently, the objective of this study was to geospatially delineate and map groundwater potential zones in Embu County, Kenya.

\section{Study area}

The study was carried out in Embu County in Kenya (Figure 1). Embu County is located on the windward side of Mt. Kenya, with agro-ecological conditions ranging from the cold and wet upper zones to the hot and dry lower zones in the Tana River Basin (Jaetzold, 2007). It falls in the shield lands of Eastern Kenya and within the upper Tana River watershed and covers approximately $2,826 \mathrm{~km} 2$. The elevation ranges from about $520 \mathrm{~m}$ to $2200 \mathrm{~m}$ above the sea level, with an average annual rainfall of $550 \mathrm{~mm}$ to $1500 \mathrm{~mm}$. The county comprises three sub-counties; Embu, Mbeere North, and Mbeere South. A rural settlement pattern characterizes Embu County except for central town area of Embu Municipality. The dominant land use system in Embu sub-County is intensive smallholder mixed farming while in Mbeere North and South livestock farming is a significant economic activity (Jaetzold, 2007). Embu Sub County occupies a total area of $729 \mathrm{~km} 2$ with an annual average bimodal rainfall of 1,500 $\mathrm{mm}$ while Mbeere North and Mbeere South Sub Counties occupy a total area of 2,092 $\mathrm{km} 2$ with an annual average bimodal rainfall of $550 \mathrm{~mm}$ (Ngetich et al., 2014).

\section{Hydrogeology}

The geology of Embu county is majorly underlain by metamorphic rocks of the Neoproterozoic Mozambique Belt and volcanics (Schluter 2006). The igneous rock around Mount Kenya was formed as a result of volcanic activity in the mountain, which is now extinct having erupted last 1.3 - 1.6 million years ago (Baker 1967). The lower slope of the mountain has never been glaciated and is comprised of unconsolidated soils or rocks from volcanic deposits, and these loose soil particles are prone to weathering and erosion (Baker 2015). Embu sub-county, located in the upper Tana river basin is dominated by volcanic rock formations with exposed fractured rocks, which tend to be higher yielding (Knoop et al. 2012; Baker et al. 2015). Phonolites, trachyphonolites, basalts, ignimbrites, and trachytes of different phases of volcanism represent volcanics (Hughes et al. 2012).

Highlands (higher than $1,500 \mathrm{~m}$ above sea level) and Midlands (1200 m to $1500 \mathrm{~m}$ above sea level) and other topographical features like hills and valleys typical of Kenya's 


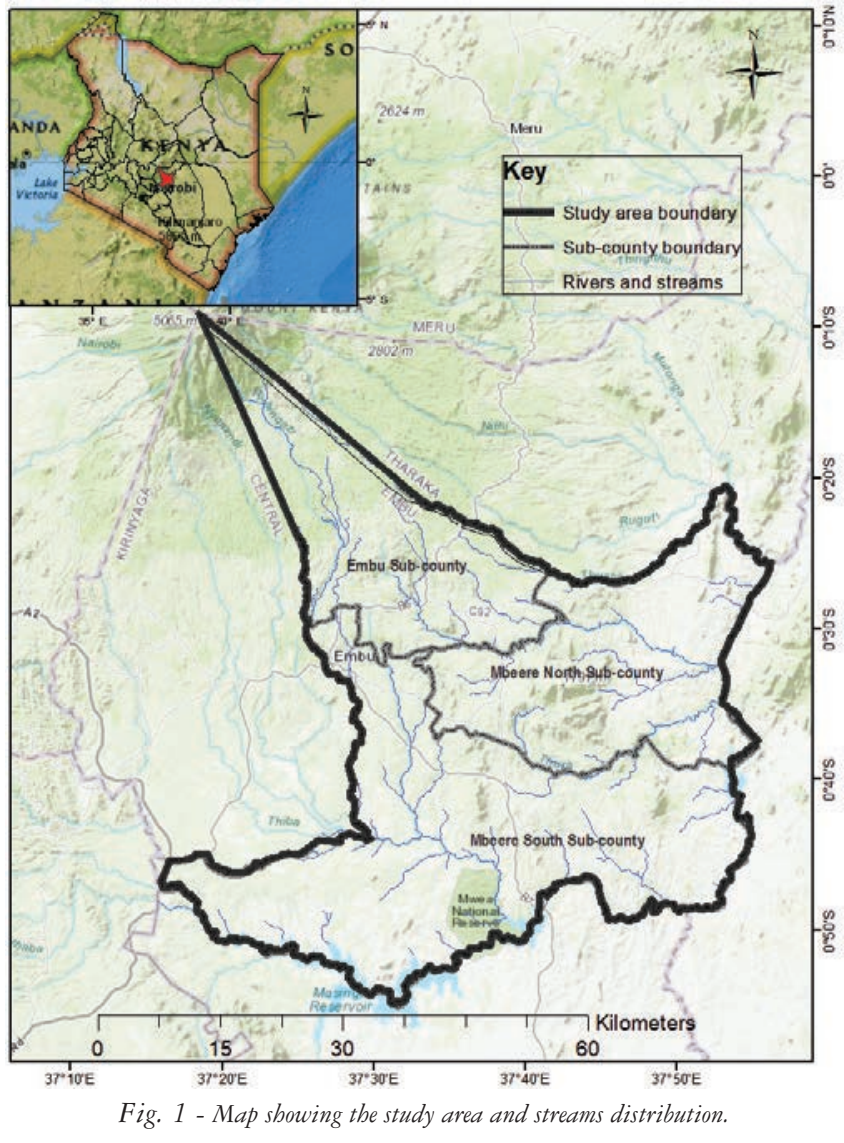

Fig. 1 - Carta dell'area di studio e della distribuzione dei corsi d'acqua.

Eastern Highlands characterize the landscape of the subcounty. Mbeere North and Mbeere South Sub Counties slope from the northwest to southwest direction and is dominated by poor yielding metamorphic rocks. In locations where groundwater is utilized, localized issues like poor understanding of seasonal variation, salinity, fluoride, iron, and manganese dominate (Knoop et al. 2012). The area is floored by rocks of the Precambrian Basement System, which include granitoid gneisses, schists, granulites and crystalline limestone (Nyambok et al. 1979).

The drainage of the main rivers and their tributaries is determined by the slopes and shape of the tertiary volcanic, the directions of the slopes of the Mt. Kenya and the structure of the basement systems. Influenced by Mount Kenya, Embu County has largely radial drainage pattern predominating the upper and middle until the streams open out in the flatter sections of the basement system floor (Baker et al. 2015). Four major rivers, namely Rupingazi, Thuci, Kii and Ena, all following a southeast direction, drain through Embu sub-county while five major rivers (Tana, Rupingazi, Thiba, Thuci, and Ena) flow through Mbeere North and Mbeere South Sub Counties.

\section{Materials and methodology}

A four-step approach was used. The first step was data acquisition, processing, and reclassification. The second step consisted of the assignment of the weights to the factors influencing groundwater potential. The third step involved the determination of the groundwater potential by integrating the thematic layers using a weighted overlay analysis approach in order to generate the groundwater potential maps. The fourth and last step was the validation of the developed groundwater potential maps through a correlation approach using existing groundwater data. The process is summarised in figure 2 .

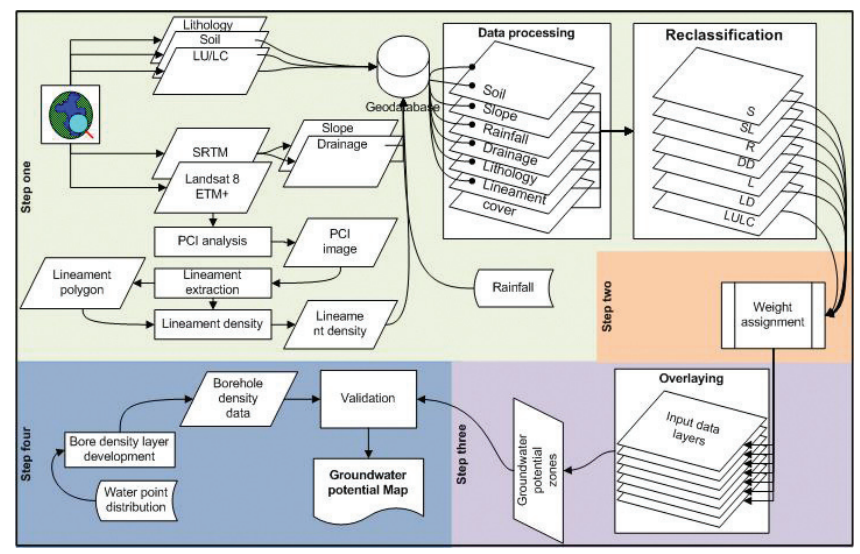

Fig. 2 - Flowchart for assessing groundwater potential zones.

Fig. 2 - Diagramma di flusso per la valutazione del potenziale idrico sotterraneo.

\section{Data acquisition and processing}

Lithology, soil and land use /land cover datasets were acquired from different online sources (Table 1). The Remote sensing data of the Landsat Enhanced Thematic Mapper $(\mathrm{ETM}+), 30 \mathrm{~m}$ resolution was used to generate the lineament density layer. The Shuttle Radar Topography Mission (SRTM), $90 \mathrm{~m}$ resolution was utilized in the drainage and slope layers' development. Gridded monthly average rainfall point data acquired from Kenya meteorological department was used to develop the rainfall layer. The details of the data types and sources are shown in Table 1.

\section{Lithology data layer}

The lithological shapefiles showing lithological distribution was processed using ArcGIS 10.4®, from lithology database of ISRIC. The study area was divided into grids and assigned the percolation values of the lithological units guided by expert knowledge from literature (ISRM 1978,1981; GSE 1995; Jha et al. 2007; Yeh et al. 2008). A map was then prepared to show zones of different lithological character concerning water potential.

\section{Soil data layer}

Soil map was prepared from soil database of ISR IC website. Permeability and infiltration, being the principal parameters required to classify soil types into hydrologic groups were extracted from the ISRIC soil database. Classification of soil types in relation to groundwater was done based on data on the type of soils obtained from digital soil and terrain database of east Africa (Batjes 2010). 
Tab. 1 - Datasets and inputs used in the in the study

Tab. 1 - Set di dati e input utilizzati nello studio.

\begin{tabular}{|l|c|c|l|}
\hline \multicolumn{1}{|c|}{ Data } & Spatial resolution & Format & \multicolumn{1}{c|}{ Source } \\
\hline Lithology data & *NA & Vector & $\begin{array}{l}\text { International Soil Reference and Information Centre (ISRIC, 2011) } \\
\text { website (www.isric.org) }\end{array}$ \\
\hline Soil data & *NA & Vector & $\begin{array}{l}\text { International Soil Reference and Information Centre (ISRIC, 2011) } \\
\text { website (www.isric.org) }\end{array}$ \\
\hline Land-use/ Land-cover & $0.5^{\circ} \times 0.5^{\circ}$ & Vector & Global Land Cover Facility (GLCF), http://glcf.umd.edu/data/lc/ \\
\hline SRTM DEM & $90 \mathrm{~m}$ & Raster & $\begin{array}{l}\text { Shuttle Radar Topography Mission (SRTM) Digital Elevation Database } \\
\text { (https://earthexplorer.usgs.gov). }\end{array}$ \\
\hline Landsat (ETM+) & $30 \mathrm{~m}$ & Raster & https://earthexplorer.usgs.gov \\
\hline Rainfall data (1981 to 2015) & $0.5^{\circ} \times 0.5^{\circ}$ & Vector & Kenya Meteorological Department (KMD) \\
\hline Water point data & NA & Vector & Open Africa (https://www.africaopendata.org) \\
\hline Rivers/streams & Vector & International Livestock Research Institute (https://www.ilri.org) \\
\hline *NA means Not Applicable & \multicolumn{2}{|l}{} \\
\hline
\end{tabular}

\section{Land-use / Land-cover data layer}

A land use/land cover layer was obtained from the Global Land Cover Facility, MODIS land cover database by Channan et al. (2014). Eight key types of land use patterns were identified in the entire study area.

\section{Slope data layer}

Slope map was extracted from the DEM using the slope function in $\operatorname{ArcGIS}{ }^{\circledR} 10.4$. For each cell, the tool calculates the maximum rate of change in value from that cell to its neighbors. The maximum change in elevation over the distance between the cell and its eight neighbors identifies the steepest downhill descent from the cell.

\section{Drainage density layer}

The drainage density map of the study area was generated from the SRTM digital elevation model (DEM) using the spatial analyst tool for ArcGIS ${ }^{\circledR}$ 10.4. The drainage density was calculated from the total stream's length of the study area per unit area using Equation 1 (Raghunath, 2006).

$$
D d=\frac{\sum L}{A}
$$

where $\mathrm{Dd}=$ is drainage density $\left(\mathrm{km} / \mathrm{km}^{2}\right), \Sigma \mathrm{L}$ is the total length of streams $(\mathrm{km})$, and $A$ is the surface area of the basin under consideration $\left(\mathrm{km}^{2}\right)$.

\section{Lineaments data layer}

Lineaments dataset was extracted from the acquired Landsat 8 ETM+ image following a step-wise lineament autoextraction process. The first step was the selection of Landsat 8 pan-sharpened reflected bands for lineament auto extraction and geospatial analysis, followed by Principal Component Analysis as described by Thannoun (2013). The second step entailed automatic lineaments extraction in PCI Geomatica ${ }^{\circledR}$ 2015 software using Line module parameters as described by Akinlalu eta al. (2017). The output was a lineament polygon which was further processed in the third step. The third step involved splitting compound lines into simple lines, editing lineaments attributes, geospatial analysis of lineaments length and density in ArcGIS $10^{4}$.

\section{Rainfall data layer}

Rainfall data layer was prepared by spatially interpolating gridded monthly average rainfall data, acquired from Kenya meteorological department, to obtain the spatial rainfall layer. Average annual rainfall was calculated after which the kriging interpolation method, using spatial analyst toolbox in ArcGIS ${ }^{\circledR} 10.4$, was applied to obtain a rainfall layer. The rainfall mapping followed steps similar to the approach used by Ngetich et al. (2014) and Kisaka et al. (2014).

Once all the required datasets were acquired, they were georeferenced using a projected coordinate system WGS 1984 UTM Zone 37S. All the layers were converted to raster format and values reclassified to a common scale of between 1 and five. The reclassification was guided by literature information and expert knowledge which led to assigning of ranks to the domain of effects of each groundwater influencing factor (Table 2).

\section{Weight assignment for hydrological modeling}

Before weight assignment, the interrelationship between the seven groundwater muti influencing factors was established based on Magesh et al. (2012). The factors that were considered to have a significant influence on the occurrence of groundwater were assigned a weight of 1.0 whereas, those with minor influence were assigned a weight of 0.5 (Magesh et al. 2012).

The relative rates of each parameter were calculated by the cumulative sum of both major and minor effect followed by a score calculation of each influencing factor using Equation 2:

$$
\text { Score }=\left[\frac{A+B}{\sum(A+B)}\right] \times 100
$$

where; " $\mathrm{A}$ " is the major effect of parameters, and " $\mathrm{B}$ " is the minor effect of parameters. 
Tab. 2 - Reclassification of groundwater influencing factor.

Tab. 2 - Riclassificazione dei fattori che influenzano le acque sotterranee.

\begin{tabular}{|c|c|c|c|c|}
\hline Factor & Domain of effect (Value) & Descriptive scale/Explanation & Rank & References \\
\hline \multirow{5}{*}{$\begin{array}{l}\text { Drainage density } \\
\left(\mathrm{km}^{-1}\right)\end{array}$} & $0.014-0.080$ & Very high infiltration potential & 5 & \multirow{5}{*}{$\begin{array}{l}\text { Sener et al. 2005; Sreedevi et al. } \\
\text { 2005; Jha et al. 2007; Sander } 2007\end{array}$} \\
\hline & $0.080-0.277$ & High infiltration potential & 4 & \\
\hline & $0.277-0.763$ & Medium infiltration potential & 3 & \\
\hline & $0.763-1.736$ & Low infiltration potential & 2 & \\
\hline & $1.736-3.365$ & Very Low infiltration potential & 1 & \\
\hline \multirow{5}{*}{ Slope (\% rise) } & 0-12.218 (Nearly level) & Very high infiltration potential & 5 & \multirow{5}{*}{$\begin{array}{l}\text { Sener et al. 2005; Sreedevi et al. } \\
\text { 2005; Jha et al. 2007; Sander 2007; } \\
\text { Yeh et al. } 2008\end{array}$} \\
\hline & $\begin{array}{l}\text { 12.218-21.992 } \\
\text { (Very gently sloping) }\end{array}$ & High infiltration potential & 4 & \\
\hline & $\begin{array}{l}21.992-36.304 \\
\text { (Gently sloping) }\end{array}$ & Medium infiltration potential & 3 & \\
\hline & $\begin{array}{l}\text { 36.304-60.012 } \\
\text { (Moderately sloping) }\end{array}$ & Low infiltration potential 10 & 2 & \\
\hline & $>60.012$ (Strongly sloping) & Very low infiltration potential & 1 & \\
\hline \multirow{5}{*}{$\begin{array}{l}\text { Lineament density } \\
\left(\mathrm{km}^{-1}\right)\end{array}$} & $0.005-0.173$ & Very low infiltration potential & 1 & \multirow{5}{*}{$\begin{array}{l}\text { Sener et al. 2005; Sreedevi et al. } \\
\text { 2005; Jha et al. 2007; Sander 2007; } \\
\text { Yeh et al. } 2008\end{array}$} \\
\hline & $0.173-0.352$ & Low infiltration potential & 2 & \\
\hline & $0.352-0.498$ & Medium infiltration potential & 3 & \\
\hline & $0.498-0.662$ & High infiltration potential & 4 & \\
\hline & $0.662-0.915$ & Very high infiltration potential & 5 & \\
\hline \multirow{4}{*}{$\begin{array}{l}\text { Landuse / Landcover } \\
\left(\mathrm{m}^{2}\right)\end{array}$} & Barren Land & Very low infiltration potential & 1 & \multirow{4}{*}{$\begin{array}{l}\text { Sanford 2002; Shaban et al. 2006; } \\
\text { Jha et al. 2007; Yeh et al. } 2008\end{array}$} \\
\hline & Bushlands and woodlands & Low infiltration potential & 2 & \\
\hline & Forests & Medium infiltration potential & 3 & \\
\hline & $\begin{array}{l}\text { Sparse agriculture and } \\
\text { Plantations }\end{array}$ & High infiltration potential & 4 & \\
\hline \multirow{5}{*}{$\begin{array}{l}\text { Lithology } \\
\left(\mathrm{m}^{2}\right)\end{array}$} & Gneiss & Favourable sites for groundwater storage & 5 & \multirow{5}{*}{$\begin{array}{l}\text { ISRM 1978,1981; GSE 1995; Jha et } \\
\text { al. 2007; Yeh et al. } 2008\end{array}$} \\
\hline & Migmatite & Favourable infiltration potential & 4 & \\
\hline & $\begin{array}{l}\text { Andesites, trachytes, } \\
\text { phonolites, }\end{array}$ & Medium infiltration potential & 3 & \\
\hline & Basalt & Medium infiltration potential & 2 & \\
\hline & $\begin{array}{l}\text { Pyroclastic unconsolidated } \\
\text { rocks }\end{array}$ & Low infiltration potential High & 1 & \\
\hline \multirow{5}{*}{ Rainfall (mm) } & $511-630$ & Very low infiltration potential & 1 & \multirow{5}{*}{$\begin{array}{l}\text { Sener et al. 2005; Jha et al. 2007; } \\
\text { Sander 2007; Yeh et al. } 2008\end{array}$} \\
\hline & $630-705$ & Low infiltration potential & 2 & \\
\hline & $705-792$ & Moderate infiltration potential & 3 & \\
\hline & $792-872$ & High infiltration potential & 4 & \\
\hline & $872-1026$ & Very high infiltration potential & 5 & \\
\hline \multirow{12}{*}{ Soil $\left(\mathrm{m}^{2}\right)$} & Acrisols & Very low infiltration potential & 1 & \multirow{12}{*}{ Jha et al. 2007; Yeh et al. 2008} \\
\hline & Alisols & High infiltration potential & 4 & \\
\hline & Andosols & Very high infiltration potential & 5 & \\
\hline & Arenosols & High infiltration potential & 4 & \\
\hline & Cambisols & High infiltration potential & 4 & \\
\hline & Ferrasols & High infiltration potential & 4 & \\
\hline & Fluvisols & Very high infiltration potential & 5 & \\
\hline & Gleysols & Low infiltration potential & 2 & \\
\hline & Luvisols & Moderate infiltration potential & 3 & \\
\hline & Nitisols & High infiltration potential & 4 & \\
\hline & Regosols & Very high infiltration potential & 5 & \\
\hline & Vertisols & Low infiltration potential & 2 & \\
\hline
\end{tabular}


Tab. 3 - Effect of groundwater influencing factor, relative rates and score for each potential factor (modified from Magesh et al. 2012).

Tab. 3 - Effetto dei fattori che influenzano le acque sotterranee, dei tassi relativi e dei punteggi per ciascun fattore potenziale (modificato da Magesh et al. 2012).

\begin{tabular}{|c|c|c|c|c|c|c|c|c|c|c|c|}
\hline & 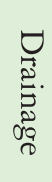 & 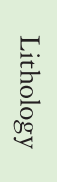 & 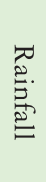 & 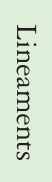 & $\underset{*}{\stackrel{\overbrace{}}{\leftrightarrows}}$ & $\frac{\infty}{\frac{\infty}{C}}$ & ஜ. & $>$ & $\varpi$ & 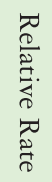 & 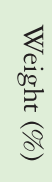 \\
\hline Drainage & - & 0 & 0 & 0.5 & 1 & 0 & 0 & 1 & 0.5 & 1.5 & 10 \\
\hline Lithology & 1 & - & 0 & 1 & 1 & 0 & 1 & 4 & 0 & 4 & 27 \\
\hline Rainfall & 1 & 0 & - & 0 & 0 & 0 & 0.5 & 1 & 0.5 & 1.5 & 10 \\
\hline Lineaments & 1 & 0 & 0 & - & 1 & 0 & 0 & 2 & 0 & 2 & 13 \\
\hline Landuse/Landcover & & 0.5 & 1 & 0.5 & - & 0 & 0.5 & 1 & 1.5 & 2.5 & 17 \\
\hline Slope & 1 & 0 & 1 & 0 & 0.5 & - & 0 & 2 & 0.5 & 2.5 & 17 \\
\hline Soil & 0 & 0 & 0 & 0 & 1 & 0 & - & 1 & 0 & 1 & 7 \\
\hline Summation & & & & & & & & & & 15 & 100 \\
\hline
\end{tabular}

\section{Groundwater potential map}

The weighted overlay tool in the spatial analyst toolbox of $\operatorname{ArcGIS}{ }^{\circledR} 10.4$ was used to overlay the scaled thematic layers. The derived weights from Table 3 were applied as the $\%$ influence (the influence of the factor compared to the other criteria as a percentage of 100). The evaluation scale was set at five to allow the overlay model to generate the potential zones up to a maximum of five classes. The output groundwater potential map had five relative classes; very low, low, moderate, high and very high.

\section{Validation of the GIS-based model}

The validation of the model result was accomplished by comparing the groundwater potential map produced with the borehole density map of the study area. The borehole distribution density map was developed using water well distribution dataset from Open Africa (Open Africa 2017). Given the none uniformity of the borehole distribution data, an equivalent area was generated from the model output for comparative purposes. The density map was generated using ordinary kriging interpolation and applying a spherical semivariogram model in ArcGIS ${ }^{\circledR}$ 10.4. The borehole density map was then reclassified to the same scale as that of groundwater potential map/model output. The two maps were then compared using the minus tool in the spatial analyst tool of $\operatorname{ArcGIS}{ }^{\circledR} 10.4$ resulting in a suitability difference map. From the suitability difference map, the difference between the observed and the modeled outputs was retrieved from the attribute table and both the area (in ha) and the level of agreement $(\%)$ computed.

\section{Results and discussion Factors influencing groundwater recharge potential Drainage density}

The average drainage density of the study area was 0.90 $\mathrm{km} / \mathrm{km}^{2}$ (Fig. 3a). The drainage density was higher in the northern part with an average of about $2.27 \mathrm{~km} / \mathrm{km}^{2}$. In the central part of the study area, the drainage density ranged from $0.08-0.76 \mathrm{~km} / \mathrm{km}^{2}$.

Drainage areas with high drainage density is an indication that a large proportion of the precipitation is lost in the form of surface runoff. On the other hand, a low drainage density indicates that most rainfall infiltrates the ground and few channels are required to carry the runoff. The results suggest moderate to high surface runoff generation potential in the study area. High drainage density is indicative of low groundwater potential due to a high likelihood of significant surface runoff generation.

\section{Slope map}

The slope of the study area was found to vary between 6 and $89 \%$ rise (Fig. 3b). The north-western and the central part of the study area had a high slope percentage while the South-Western, South and the Eastern part of the study area had relatively flat terrain. The slope is a factor that has a direct influence on the rainfall water infiltration. It controls the rainfall water, whether it will be lost as runoff water or remains on the ground surface for long enough to infiltrate and recharge the groundwater (Abdalla 2012). Steeper slopes generate less recharge because water runs rapidly off the surface during rainfall, allowing insufficient time to infiltrate and recharge the profile. Given the inverse relationship between slope and groundwater recharge potential, low slope percentage rise is assigned a higher rank of the probability of groundwater availability while a higher slope percentage rise is categorised as a lower rank due to relatively high run-off. This is also supported by Nampak et al. (2014) who observed that a lower slope is indicative of high topographic wetness index and is positively correlated with groundwater occurrence which is indicative of a higher groundwater potential.

\section{Lithology map}

The study area consists of several lithological units (Fig. 3c). This includes metamorphic rocks (gneiss and migmatite) which cover the central and southern part of the study area. These types of rocks occur in a weathered 

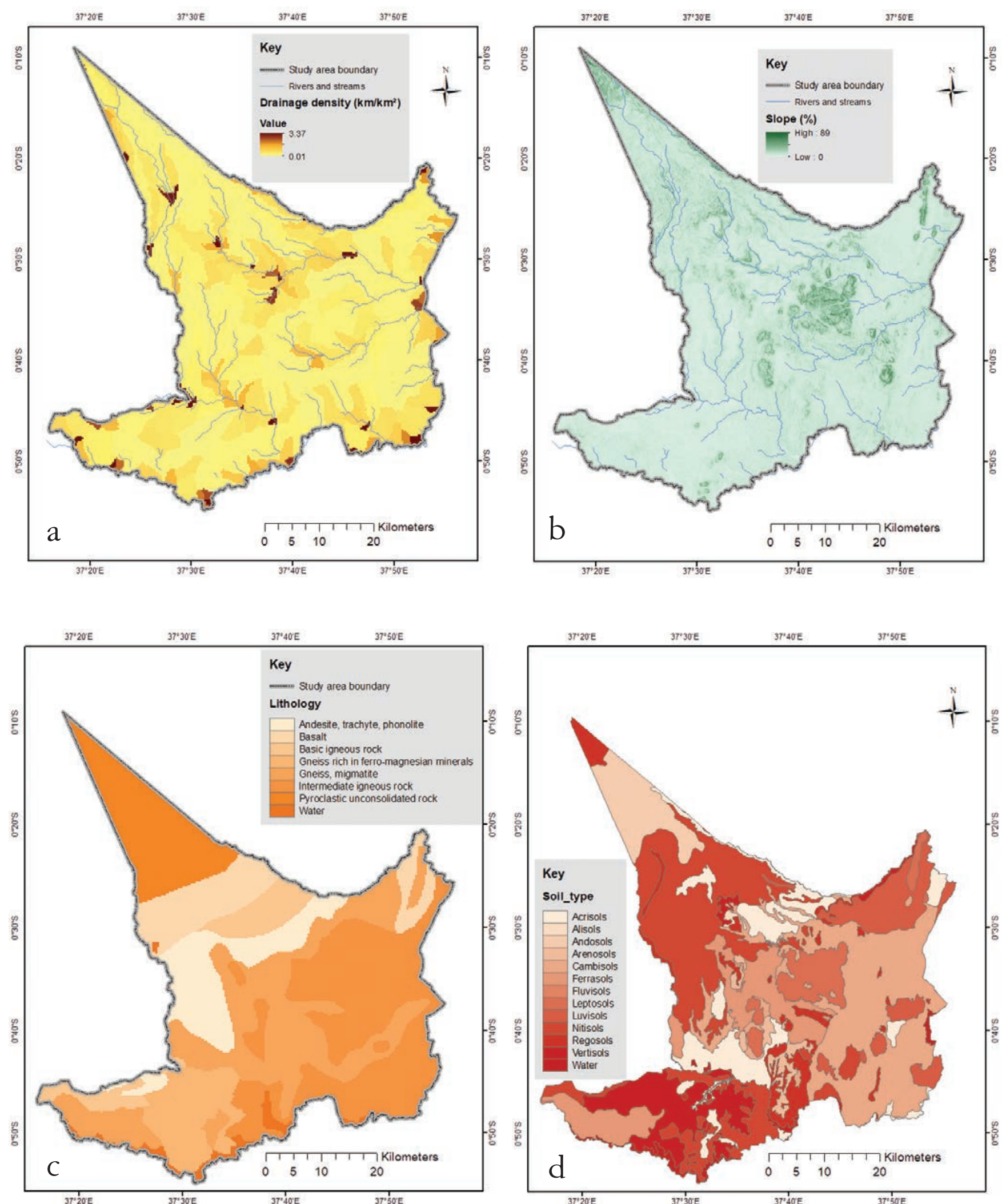

Fig. 3 - Input parameters: (a) drainage density, (b) slope, (c) lithology and (d) soil type of the study area.

Fig. 3 - Parametri di input: (a) densità di drenaggio, (b) pendenza, (c) litologia e (d) tipo di suolo dell'area di studio. 

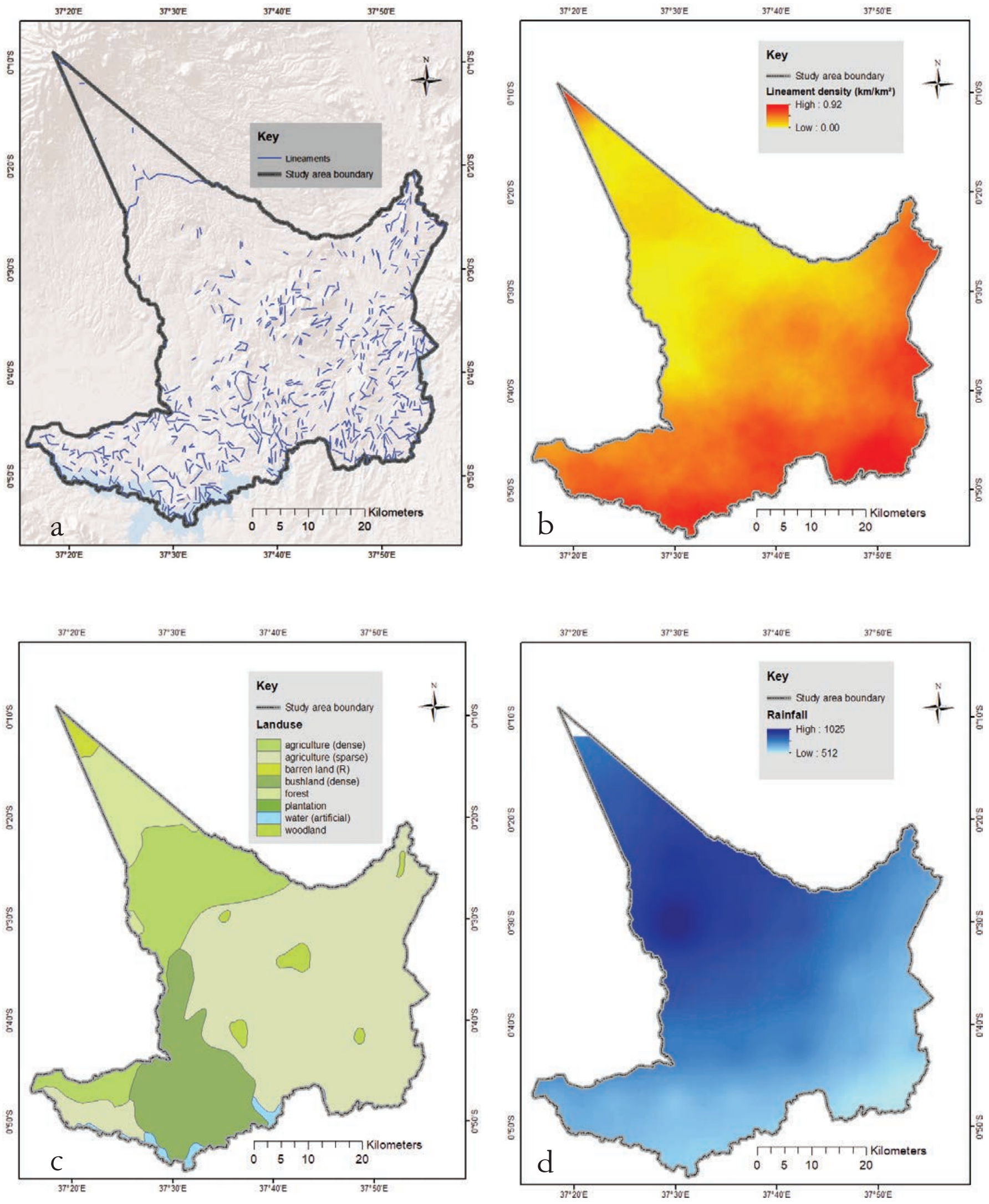

Fig. 4 - Input parameters: (a) lineaments, (b) lineament density, (c) land uselland cover and (d) rainfall amount of the study area.

Fig. 4 - Parametri di input: (a) lineamenti, (b) densità di lineamenti, (c) uso del suolo / copertura del suolo e (d) quantità di precipitazioni nell'area di studio. 
basement complex environment. This combination results in a high potential but ubiquitous groundwater system. Pyroclastic unconsolidated rocks (agglomerates, lapilli tephra, coarse ash, and fine ash) are found on the northwestern side of the study area. This is at the slopes of Mount Kenya. These rocks were produced from the consolidation of fine fragments accumulations into a coherent rock indicative of groundwater movement difficulty; hence this area could be considered as a poor groundwater potential zone. Consequently, this area was assigned a low potential value. The remaining part of the study area consists mainly of intermediate igneous rocks (andesites, trachytes, phonolites, basalt). These types of rocks are the most dominant. These areas are generally considered as a moderate potential zone for groundwater (Earl 2015). Lithology influences soil texture and drainage density thus provide an essential indication of the rate that rainfall infiltrates compared with the surface runoff (Abdalla 2012). It also influences the stream system networks rockmass strength (resistance to weathering) and lineaments.

\section{Soil data layer}

Thirteen soil units comprising Acrisols, Alisols, Andosols, Arenosols, Cambisols, Ferrasols, Fluvisols, Gleysols, Luvisols, Nitisols, Regosols, and Vertisols are distributed across the study area (Fig. 3d). Ranks were assigned subjectively to each soil unit after taking into account the type of soil and its water-holding capacity. The permeability of the topsoil is very crucial to infiltration potential vis-à-vis groundwater accumulation (Shaban et al. 2006; Jha et al. 2007; Yeh et al. 2008). Thus, soils, such as Acrisols which are relatively sandy have a low water-holding capacity and were assigned a lower score. This soil is located partly on the northern and western regions. Vertisols, Andosols, Fluvisols, and Regosols which have a relatively low bulk density, high clay content and hence high water-holding capacity were assigned higher scores. These areas are located in south-western and southern parts of the study area.

\section{Lineaments data layer}

The Eastern, South and South-western parts of the study areas had high lineaments resulting in high lineament densities of over $0.5 \mathrm{~km} / \mathrm{km}^{2}$ (Figg. $4 \mathrm{a}$ and $4 \mathrm{~b}$ ). The northern and northwestern parts of the study area had a low number of lineaments, hence low lineament density. Areas with highest lineament density of between 0.662 to $0.915 \mathrm{~km} / \mathrm{km}^{2}$ were assigned a higher rank while areas with lowest lineament density of between $0.005-0.173 \mathrm{~km} / \mathrm{km}^{2}$ were assigned a lower rank. It can be inferred that the higher the lineament density, the higher the probability of the groundwater potential. The higher the lineament density, the higher the chances of the groundwater occurrence, (Nampak et al. 2014; Selvam et al. 2015) and vice versa.

\section{Land cover / Land use layer}

The study area consisted of eight types of land uses and land cover (Fig. 4c). These were crop agriculture (both dense and sparse), barren land, forest, plantation, and woodland. Land-uses influences the fate of rainwater. Depending on the land-uses, the rainfall water can evaporate, infiltrate into the soil or lost/drained to the sea as runoff (Nanda et al. 2017). Cultivated lands for agriculture were assigned a high rank because it is mostly associated with good underlying groundwater potential sites, fine/medium texture. One of the dominant land use/land cover categories in the area is bushlands which were assigned a lower rank. The land use/ land cover areas such as barren lands, have poor water holding capacity and therefore were assigned low rank.

\section{Rainfall map}

Rainfall is a significant source of recharge. It plays a vital role in the hydrologic cycle, which controls groundwater potential. The rainfall amount determines the amount of water that would be percolating into the groundwater system as the major source of recharge (Nampak et al. 2014). The annual average rainfall of the study area ranged from $510 \mathrm{~mm}$ to $1025 \mathrm{~mm}$ (Fig. 4d). Hence, areas with a high amount of rainfall were assigned higher rank value compared to areas with low annual rainfall during the analysis. The annual rainfall of the study area was grouped into five classes namely very low (below $1100 \mathrm{~mm}$ ), low (1100-1200 mm), medium (1200-1300 mm), high (1300-1400 mm) and very high (above $1400 \mathrm{~mm}$ )

\section{Groundwater potential zones}

The groundwater potential map is shown in figure 5. It consists of five classes, from the lowest to the highest potential degree: very low potential (1), low potential (2), moderate potential (3), high potential (4) and very high potential zones (5).

The very high potential zones cover about $5 \%$ of the study area (Tab. 4) and correspond mostly with dense agricultural land-use system. The predominant soil type was Nitisols and Acrisols soils which have a high water holding capacities. The high groundwater potential zone has the highest cover of the study area (about $73 \%$, Tab. 4). These zones coincided with the low drainage density and high lineaments density areas. The predominant soil type was the Vertisols, Arenosols, Cambisols, and Regosols. The low potential zones are mainly present in the mountain peaks which have cliffs, where low fractured rocks formation exists. These areas had high drainage density and low lineament density and covered about $2 \%$ of the study area. The drainage density is an inverse function of permeability, meaning, the less permeable a rock is, the less the infiltration of rainfall, which conversely tends to be concentrated in surface runoff (Thomas and Duraisamy 2017). As observed by Mosaad (2017) in Egypt, most of the high potential zones in the study area had low drainage density values reflecting the relatively permeable sub-surface strata and medium relief, hence more infiltration than runoff and groundwater recharge occurs.

High lineament occurrence significantly controls the permeability of the rocks in the basin apart from other parameters, in which most of the springs and drainage lines follow these fracture zones that would favor groundwater flow.

The final groundwater potential zones map is given in figure 5. Areas with a high concentration of lineaments 
and high lineament density coincided with high to very high groundwater potential areas. This can be attributed to lineament related joints and fractures in the underlying rocks which can structurally control the drainage pattern of an area influencing both the groundwater and surface water flow directions (Anudu et al. 2011). Lineaments reflect rock structures through which water can percolate and travel up to several kilometers and depending upon the terrain, the lineament is a zone of influence (Lee et al. 2012). Many studies have shown that groundwater potential increase with increasing lineament density (Edet et al. 1994; Anudu et al. 2011; Mogaji et al. 2012).

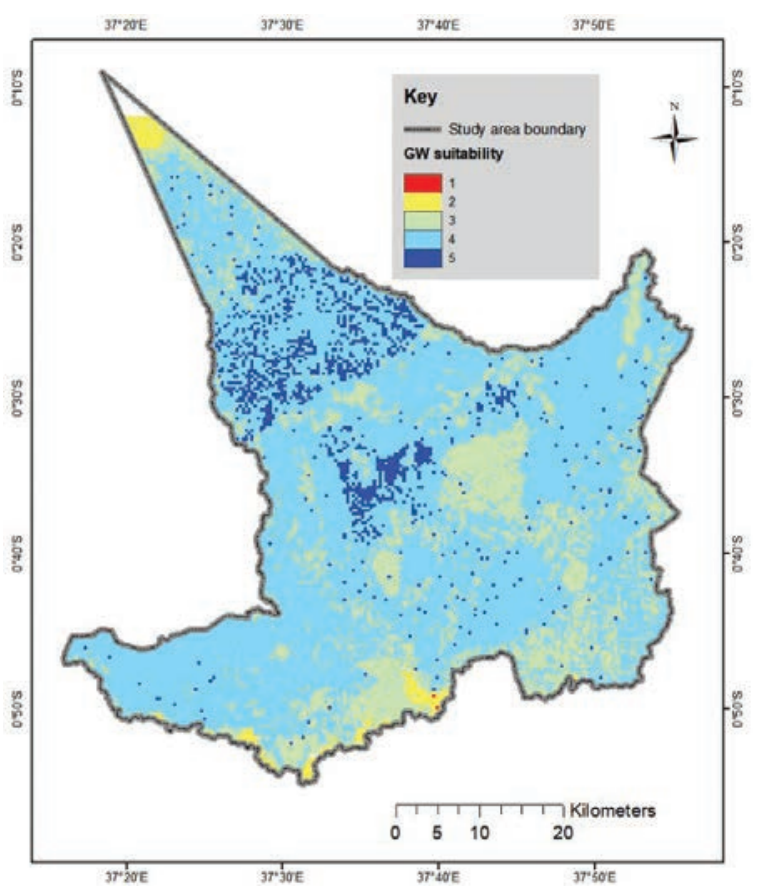

Fig. 5 - Groundwater potential zones in Embu County.

Fig. 5 - Zonazione del potenziale idrico sotterraneo nella contea di Embu.

Tab. 4 - The area coverage of the groundwater potential zones in Embu County.

Tab. 4 - Copertura areale delle varie zone di potenziale idrico sotterraneo nella Contea di Embu.

\begin{tabular}{|c|c|c|c|}
\hline Class & Groundwater potential zone & Area coverage $\left(\mathrm{km}^{2}\right)$ & $\%$ \\
\hline 1 & Very low & 0.29 & $0 \%$ \\
\hline 2 & Low & 45.50 & $2 \%$ \\
\hline 3 & Moderate & 565.35 & $20 \%$ \\
\hline 4 & High & 2019.0 & $73 \%$ \\
\hline 5 & Very high & 149.53 & $5 \%$ \\
\hline
\end{tabular}

\section{Validation}

The validation process was based on the borehole spatial distribution data (Fig. 6a), used to derived borehole density map (Fig. 6b) and the observed groundwater potential output map (Fig. 5). The reclassification of the density map was based on the assumption that the higher the distribution density, the higher the ground water potential (Fig. 6c). The selection of the approach was informed by the lack of detailed borehole data of the study area, except the borehole location data (Adiat et al. 2012). For comparative purposes, an equivalent area of the modeled groundwater suitability map was clipped (Fig. 6d).

From the study, it was observed that the zonation of groundwater potential using integrated GIS and RS techniquesisstrongly related to theavailableboreholeinventory data (Fig. 6a). The number of wells/boreholes was few in the poor potential zone suggesting a good confirmation of the result. From the comparative evaluation, it was observed that there was a $62 \%$ total agreement with 0 difference between the observed and the modeled groundwater potential maps (Tab. 5). The model underestimated about $4 \%$ and overestimated about $31 \%$, but both were within a moderately suitable range.

Tab. 5 - The difference between the observed data and the model output.

Tab. 5 - La differenza tra i dati osservati e l'output del modello.

\begin{tabular}{|c|c|c|}
\hline *Difference & Area (ha) & $\%$ Agreement \\
\hline-1 & 3294 & $4 \%$ \\
\hline 0 & 54249 & $62 \%$ \\
\hline 1 & 27431 & $31 \%$ \\
\hline 2 & 2289 & $0 \%$ \\
\hline 3 & 6 & $100 \%$ \\
\hline Total & 87268 & $3 \%$ \\
\hline $\begin{array}{l}\text { * is the difference between the borehole density and the derived } \\
\text { groundwater potential maps }\end{array}$ \\
\hline
\end{tabular}

\section{Conclusion}

The combined application of RS and GIS techniques are found to be useful tools in the identification of groundwater potential areas in this study area due to the low cost, efficiency, workforce and time involved while using this approach. Approximately, $78 \%$ of the total area was within the 'high' to 'very high' groundwater potential zones indicating that significant parts of the study area have good groundwater potential. About $20 \%$ of the study area was of moderate potential, while the low and very low potential zones comprised about $2 \%$ of the study area. The outcomes of the research can be helpful in the future as first-hand information planners and local authorities for assessment, administration and sustainable utilization of water resources in Embu County. The identified of groundwater potential sites can aid the Embu county administration in the planning and management of groundwater resources in the drier parts of the county. 

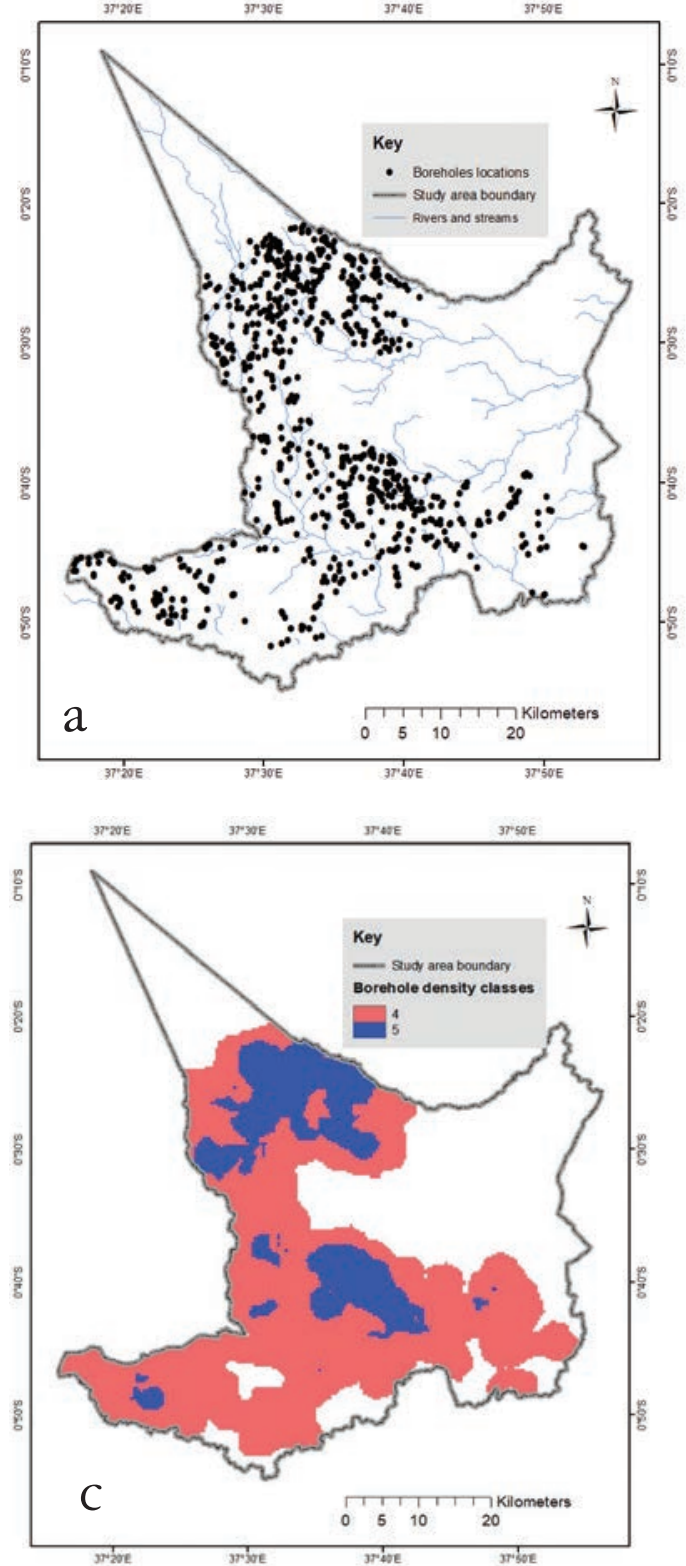

Fig. 6 - Validation maps: (a) Boreholes distribution (b) Borehole distribution density. / Observed data (c) Reclassified borehole distribution density (d) Groundwater potential map/model output (e) Comparison of the groundwater potential map produced with the borehole distribution in the study area.

Fig. 6 - Mappe di validazione: (a) Distribuzione dei pozzi (b) Densità di distribuzione del pozzo. / Dati osservati (c) Densità di distribuzione del pozzo riclassificata (d) Mappa del potenziale idrico sotterraneo / output del modello (e) Confronto tra il potenziale idrico sotterraneo ottenuto e la distribuzione dei pozzi nell'area di studio.
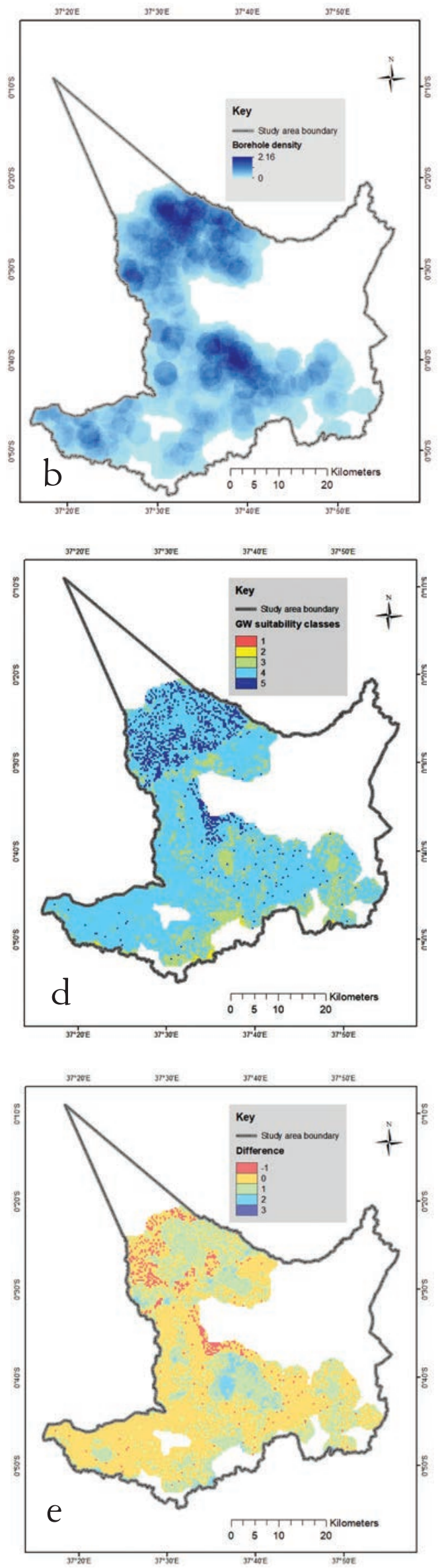


\section{REFERENCES}

Abdalla F (2012) Mapping of groundwater prospective zones using remote sensing and GIS techniques: A case study from the Central Eastern Desert, Egypt. J. African Earth Sci. 70:8-17. doi:10.1016/j. jafrearsci.2012.05.003.

Adiat K N, Nawawi M N M, Abdullah K (2012) Assessing the accuracy of GIS-based elementary multi criteria decision analysis as a spatial prediction tool - A case of predicting potential zones of sustainable groundwater resources. J. Hydrol. 440-441:75-89. doi:10.1016/j.jhydrol.2012.03.028.

Akinlalu, A A, Adegbuyiro A, Adiat K A N, Akeredolu B E, Lateef W Y (2017) Application of multi-criteria decision analysis in prediction of groundwater resources potential: A case of Oke-Ana, Ilesa Area Southwestern, Nigeria. NRIAG J. Astron. Geophys. 6:184200. doi:10.1016/j.nrjag.2017.03.001.

Anudu GK, Essien BI, Onuba LN, Ikpokonte E (2011) Lineament Analysis and Interpretation for Assessment of Groundwater Potential of Wamba and Adjoining Areas, Nasarawa State, Northcentral Nigeria. J. Appl. Technol. Environ. Sanit. 1:185-198.

Baker, B.H. (1967). Geology of the Mount Kenya area. Geological Survey of Kenya Report 79(78): 464-465.

Baker T, Kiptala J, Olaka L, and Oates N (2015) Baseline Review and Ecosystem Services Assessment of the Tana River Basin, Kenya. Colombo, Sri Lanka: International Water Management Institute (IWMI). doi:10.5337/2015.223

Balamurugan G, Seshan K, Bera S (2017) Frequency ratio model for groundwater potential mapping and its sustainable management in cold desert, India. J. King Saud Univ. - Sci. 29:333-347. doi:10.1016/j.jksus.2016.08.003.

Balwant H, Baier K, Jha R (2018) Impact of urbanization on groundwater recharge and urban water balance for the city of Hyderabad, India. Int. Soil Water Conserv. Res. 6:51-62. doi:10.1016/j.iswcr.2017.10.003.

Batjes NH (2010) A global framework of soil organic carbon stocks under native vegetation for use with the simple assessment option of the Carbon Benefits Project system. Carbon Benefits Project (CBP) and ISRIC - World Soil Information. Wageningen.

Bear, L.M. (1952). A geological reconnaissance of the area south-east of Embu. Report of the Geological Survey of Kenya Issue 23.

Channan S, Collins K, Emanuel W R (2014) Global mosaics of the standard MODIS land cover type data. University of Maryland and the Pacific Northwest National Laboratory, College Park, Maryland, USA. http://glcf.umd.edu/data/lc/ (accessed on 12th June 2017).

CoK (2010) Constitution of Kenya. Government Printer - Nairobi, Kenya. Pp 32 .

Dinesh-Kumar P K, Gopinath G and Seralathan P (2007) Application of remote sensing and GIS for the demarcation of groundwater potential zones of a river basin in Kerala, southwest coast of India, International Journal of Remote Sensing, 28:24, 5583-5601, doi: $10.1080 / 01431160601086050$

Edet A E, Teme C S, Okereke C S and Esu E O (1994) Lineament analysis for groundwater exploration in Precambrian Oban Massif and Obudu Plateau, SE Nigeria. Journal of Mining and Geology, 30 (1):87-95.

GSE (1995) - Geological Society Engineering Group Working Party Report. The description and classification of weathered rocks for engineering purposes. Quarterly Journal of Engineering Geology 28 (3):207-242.

Hornero J, Manzano M, Ortega L, Custodio E (2016) Science of the Total Environment Integrating soil water and tracer balances, numerical modelling and GIS tools to estimate regional groundwater recharge: Application to the Alcadozo Aquifer System (SE Spain). Sci. Total Environ. 568:415-432. doi:10.1016/j.scitotenv.2016.06.011.
Hughes HJ, Bouillon S, André L, Cardinal D (2012) The effects of weathering variability and anthropogenic pressures upon silicon cycling in an intertropical watershed (Tana River, Kenya). Chemical Geology 308-309: 18-25.

Huho J, Mugalavai E (2010) The Effects of Droughts on Food Security in Kenya. International Journal of Climate Change: Impacts and responses 2:61-72. doi:10.18848/1835-7156/CGP/v02i02/37312.

ISRM - International Society for Rock Mechanics (1978) Suggested methods for the quantitative description of discontinuities in rock masses. Int. Journ. Rock Mech. Min. Sci. \& Geom. Abstr. 15(6):319-368.

ISRM - International Society for Rock Mechanics (1981) Basic geotechnical description of rock masses. Int. Journ. Rock Mech. Min. Sci. \& Geom. Abstr. 18:85-110.

Jaetzold R, Schmidt H, Hornet ZB, Shisanya CA (2007) Farm Management Handbook of Kenya. Natural Conditions and Farm Information. 2nd Edition. Vol.11/ C. Eastern Province. Ministry of Agriculture/GTZ, Nairobi, Kenya.

Jha MK, Chowdary VM, Chowdhury A (2010) Groundwater assessment in Salboni Block, West Bengal (India) using remote sensing, geographical information system and multi-criteria decision analysis techniques. Hydrogeol J. 18 (7):1713-1728. doi:10.1007/s10040010-0631-z.

Jha MK, Chowdhury A, Chowdary VM and Peiffer S (2007) Groundwater management and development by integrated remote sensing and geographic information systems: Prospects and constraints. Water Resources Management, 21:427-467.

JICA - Japan International Cooperation Agency (2012) The project on the development of the national water master plan 2030 in the Republic of Kenya, final report Volume - V. Nairobi, Kenya. Pp 413.

Kenya Vision 2030 (2010) Ministry of State for Planning, National Development \& Vision 2030

Kisaka MO, Ngetich FK, Mugwe JN, Mugendi D, Mairura F (2014) Rainfall Variability, Drought Characterization, and Efficacy of Rainfall Data Reconstruction: Case of Eastern Kenya. Adv. Meteorol. 2015:1-17.

Knoop, L, Sambalino F, Van Steenbergen F (2012) Securing water and land in the Tana Basin: A resource book for water managers and practitioners. Wageningen, the Netherlands: 3R Water Secretariat.

Lee S, Kim YS, Oh HJ (2012) Application of a weights-of-evidence method and GIS to regional groundwater productivity potential mapping. J. Environ. Manage. 96:91-105. doi:10.1016/j.jenvman.2011.09.016.

Lee S, Song K, Park I (2015) Regional groundwater productivity potential mapping using a geographic information system (GIS) based artificial neural network model Saro. Hydrogeol. J. 1511-1527. doi:10.1007/s10040-012-0894-7.

Machiwal D, Jha MK and Mal BC (2011) Assessment of groundwater potential in a semi-arid region of India using remote sensing, GIS and MCDM techniques. Water Resour. Manage. 25: 1359. doi:10.1007/s11269-010-9749-y.

Magesh N S, Chandrasekar N, Soundranayagam J P (2012) Delineation of groundwater potential zones in Theni district, Tamil Nadu, using remote sensing, GIS and MIF techniques. Geosci. Front. 3:189196. doi:10.1016/j.gsf.2011.10.007.

Mallast U, Gloaguen R, Geyer S (2011) Derivation of groundwater flow-paths based on semi-automatic extraction of lineaments from remote sensing data. Hydrol. Earth Syst. Sci. 15:2665-2678. doi:10.5194/hess-15-2665-2011.

Mati B, Muchiri J M, Njenga K, Penning de Vries F, Merrey D (2005) Assessing water availability under pastoral livestock systems in drought-prone Isiolo District, Kenya. Colombo, Sri Lanka: International Water Management Institute (IWMI). ix, 27p. (IWMI Working Paper 106) doi:10.3910/2009.290. 
Mogaji K, Aboyeji OS, Omusuyi GO (2012) Mapping of lineaments for groundwater targeting in the basement complex region area of Ondo State, Nigeria, using remotely sensed data. Int. J. Water Resour. Environ. Eng. 3:150-160.

Mokadem N, Boughariou E, Mudarra M, Ben F, Andreo B, Hamed Y, Bouri S (2018) Mapping potential zones for groundwater recharge and its evaluation in arid environments using a GIS approach: Case study of North Gafsa Basin (Central Tunisia). J. African Earth Sci. 141:107-117. doi:10.1016/j.jafrearsci.2018.02.007.

Mosaad S (2017) Geomorphologic and geologic overview for water resources development: Kharit basin, Eastern Desert, Egypt. J. African Earth Sci. 134:56-72. doi:10.1016/j.jafrearsci.2017.06.008.

Murthy K S R, Mamob A G (2009) Multi-criteria decision evaluation in groundwater zones identification in Moyale-Teltele subbasin, South Ethiopia. Int. Jour. Remote Sensing, 30:2729-2740, doi:10.1080/01431160802468255.

Nampak H, Pradhan B, Manap MA (2014) Application of GIS based data driven evidential belief function model to predict groundwater potential zonation. J. Hydrol. 513:283-300. doi:10.1016/j.jhydrol.2014.02.053

Nanda S, Annadurai R, Barik K K (2017) Remote Sensing Applications: Society and Environment Geospatial decipherment of groundwater potential of Kattankolathur block of Tamil Nadu using MCDM techniques. Remote Sens. Appl. Soc. Environ. 8:240250. doi:10.1016/j.rsase.2017.10.002.

Ngetich K F, Mucheru-muna M, Mugwe J N, Shisanya CA, Diels J, Mugendi D N (2014) Length of growing season, rainfall temporal distribution, onset and cessation dates in the Kenyan highlands. Agric. For. Meteorol. J. 188:24-32.

Nyambok I O, Ongweny G S (1979) Hydrology, Soil Erosion, and Sedimentation Source: Ecological Bulletins, No. 29, An African Dam: Ecological Survey of the. Ecological Bulletins, 29:17-37.

Oh H J, Kim Y S, Choi J K, Park E, Lee S (2011) GIS mapping of regional probabilistic groundwater potential in the area of Pohang City, Korea. J. Hydrol. 399:158-172. doi:10.1016/j.jhydrol.2010.12.027.

Open Africa (2018). (https://www.africaopendata.org). (Accessed on 24th May 2017).

Raghunath HM (2006) Hydrology: Principles, Analysis, Design, Second edi. ed. New Age International (P) Limited, Publishers, Manipal, Karnataka, India. Pp 477.

Rahmati O, Reza H, Melesse AM (2016) Application of GIS-based data driven random forest and maximum entropy models for groundwater potential mapping: A case study at Mehran Region, Iran. Catena 137:360-372. doi:10.1016/j.catena.2015.10.010.

Ramírez-hern J, Martín-loeches M, Reyes-l J, Martínez-santos P, Temi J (2018) Journal of African Earth Sciences Comparison of RS / GIS analysis with classic mapping approaches for siting low-yield boreholes for hand pumps in crystalline terrains. An application to rural communities of the Caimbambo province, Angola 138:22-31. doi:10.1016/j.jafrearsci.2017.10.025.

Sander P, Chesley M M, Minor T B (1996) Groundwater assessment using remote sensing and GIS in a rural groundwater project in Ghana: lessons learned. Hydrogeol. J. 4:40-4.

Sander P (2007) Lineaments in groundwater exploration: A review of applications and limitations. Hydrogeol. Jour. 15:71-74.

Sanford W (2002) Recharge and groundwater models: an overview. Hydrogeology Journal 10(1):110-120.

Schluter T (2006) Geological Atlas of Africa, with Notes on Stratigraphy, Economic Geology, Geohazards and Geosites of Each Country. Chapter 4. Kenya. Springer-Verlag

Selvam S, Magesh N S, Chidambaram S, Rajamanickam M, Sashikkumar M C (2015) A GIS based identification of groundwater recharge potential zones using RS and IF technique: A case study in Ottapidaram taluk, Tuticorin district, Tamil Nadu. Environmental Earth Sciences, 73:3785-3799.
Sener E, Davraz A, Ozcelik M (2005) An integration of GIS and remote sensing in groundwater investigations: A case study in Burdur, Turkey. Hydrogeol. J., 13:826-834.

Senthil M (2017) Quantification of benzene in groundwater sources and risk analysis in a popular South Indian Pilgrimage City: A GIS based approach. Arab. J. Chem. 10:2523-2533. doi:10.1016/j.arabjc.2013.09.022.

Shaban A, Khawlie M, Abdallah C (2006) Use of remote sensing and GIS to determine recharge potential zone: the case of Occidental Lebanon. Hydrogeology Journal 14, 433-443.

Singh A K, Prakash S R (2002) An integrated approach of remote sensing, geophysics and GIS to evaluation of groundwater potentiality of Ojhala sub-watershed, Mirjapur district, U. P., India, http:// www.GISdevelopment.net (Accessed on 24th May 2017).

Sreedevi P D, Subrahmanyam K, Ahmed S (2005) Integrating approach for delineating potential zones to explore for groundwater in the Pageru river basin, Cuddapah district, Andhra Pradesh, India. Hydrogeol. J. 13:534-543.

Thannoun R G (2013) Automatic Extraction and Geospatial Analysis of Lineaments and their Tectonic Significance in some areas of Northern Iraq using Remote Sensing Techniques and GIS. Int. J. Enhanc. Res. Sci. Technol. Eng. 2:1-11.

Thapa R, Gupta S, Reddy D V, Guin S, Kaur H (2017) Assessment of groundwater potential zones using multi-influencing factor (MIF) and GIS: a case study from Birbhum district, West Bengal. Appl. Water Sci. 7:4117-4131, doi:10.1007/s13201-017-0571-z.

Thomas R, Duraisamy V (2018) The Egyptian Journal of Remote Sensing and Space Sciences Hydrogeological delineation of groundwater vulnerability to droughts in semi-arid areas of western Ahmednagar district. Egypt. J. Remote Sens. Sp. Sci. 21:121-137. doi:10.1016/j. ejrs.2016.11.008

Tiwari A K, Lavy M, Amanzio G, De Maio M (2017) Identification of artificial groundwater recharging zone using a GIS-based fuzzy logic approach: a case study in a coal mine area of the Damodar Valley, India. Applied Water Science, 7(8), 4513-4524. doi:10.1007/ s13201-017-0603-8.

Yeh H F, Lee C H, Hsu K C, Chang P H (2008) GIS for the Assessment of the Groundwater Recharge Potential Zone. Environ. Geol. 58:185-195. doi:10.1007/s00254-008-1504-9. 